\title{
Pengaruh DPK, NPF, dan Inflasi terhadap Penyaluran Pembiayaan UMKM di Bank Syariah
}

\section{Influence of TPF, NPF, and inflation on MSME financing allocation in Islamic bank}

\section{Agnina Ilma Nur Annisa}

Program Studi D4 Keuangan Syariah, Politeknik Negeri Bandung

E-mail: agninaina97@gmail.com

\section{Diharpi Herli Setyowati}

Jurusan Akuntansi, Politeknik Negeri Bandung

E-mail: diharpi.herli@polban.ac.id

\section{Ruhadi}

Jurusan Akuntansi, Politeknik Negeri Bandung

E-mail: ruhadi@polban.ac.id

\begin{abstract}
This study analyzes the influence of Third Party Funds, Non Performing Financing and Inflation of the Micro, Small and Medium Enterprise Financing Allocation of Islamic Banking in Indonesia. Population of this study is Islamic Banking listing in OJK. Sample technique used in this research is saturated sampling. The data used in this study is secondary data published by OJK during the period 2014-2018. Analysis technique used in this research is multiple linear regression analysis, using the SPSS application program. Based on the result of the analysis with a significance level of 5\%, the study shows the following result: DPK partially not have a significant influent on the Micro, Small and Medium Enterprise Financing Allocation. NPF and Inflation partially have significant effect on the MSME Financing Allocation. DPK, NPF, and Inflation simultaneoushy have a significant influent on MSME Financing Allocation. All the variables X contribute simultaneously to variable $Y$, based on the results of the analysis the coefficient of determination is $62,3 \%$, and the balance is equal to $37,7 \%$ is influenced by other variables.
\end{abstract}

Keywords: TPF, NPF, inflation and MSME financing

\section{Pendahuluan}

\subsection{Latar Belakang}

Banyak jenis bisnis yang telah dijalankan, Usaha Kecil, Mikro dan Menengah (UMKM) merupakah salah satu bisnis yang banyak digandrungi oleh masyarakat. Bank Indonesia sedang gencar mengkampanyekan peningkatan kontribusi perbankan dalam pembiayaan ke sektor UKM, karena mayoritas masyarakat Indonesia berada pada sector ini, serta melalui UKM terbukti mampu menciptakan lapangan kerja dan menyerap tenaga kerja dan memberikan kontribusi besar PDB. Maka tidak heran jika perkembangan UMKM berkembang setiap tahunnya. (Wahyudi, 2013) Hal ini menjadi peluang besar untuk semakin meningkatnya pengajuan pembiayaan khususnya dari kalangan UMKM terhadap pembiayaan UMKM. Dari keterangan tersebut seharusnya perbankan dapat menyokong pertumbuhan UMKM dengan memberikan pembiayaan yang memadai, namun dilihat dari data Statistik Perbankan Syariah OJK pada tahun 2018 porsi pembiayaan UMKM terhadap pembiayaan non-UMKM hanya sebesar 19,4\% saja. 
Pembiayaan ke sektor UMKM terkendala oleh beberapa hal. Umumnya UMKM belum memiliki format laporan keuangan yang baku, sehingga informasi keuangan bersifat kurang dapat dipercaya. Selain itu, UMKM masih terbilang baru, tidak ada jaminan dan teknologi yang memadai, dan para pengelola yang belum memiliki pengalaman dalam mengelola bisnis. (Wahyudi, 2013) Di sisi lain, bank wajib memberikan kredit atau pembiayaan UMKM berdasarkan (PBI, 2012) Peraturan Bank Indonesia Nomor 14/22/PBI/2012 tentang Pemberian Kredit Atau Pembiayaan Oleh Bank Umum dan Bantuan Teknis Dalam Rangka Pengembangan UMKM.

Tabel I.1 Daftar NPF, Inflasi, DPK dan Pembiayaan di Bank Umum Syariah Tahun 2014-2018 (Dalam Triliun)

\begin{tabular}{|c|c|c|c|c|}
\hline TAHUN & DPK & NPF & INFLASI & PEMB. UMKM \\
\hline 2014 & Rp. 193,901 & 2,80 & 6,42 & Rp. 77,231 \\
\hline 2015 & Rp. 216,656 & 4,04 & 6,38 & Rp. 51,142 \\
\hline 2016 & Rp. 253,593 & 4,76 & 3,53 & Rp. 51,257 \\
\hline 2017 & Rp. 303,837 & 4,76 & 3,81 & Rp. 56,132 \\
\hline 2018 & Rp. 345,312 & 4,25 & 3,20 & Rp. 59,676 \\
\hline
\end{tabular}

Faktor yang dapat mempengaruhi penyaluran pembiayaan salah satunya adalah jumlah DPK, yaitu salah satu sumber dana bank, dimana dana tersebut yang akan disalurkan oleh bank salah satunya untuk pembiayaan (Apriyanthi dkk., 2020). Maka semakin tinggi jumlah DPK, porsi pembiayaan UMKM akan semakin besar. Pada tabel No. I.1 menjunjukkan jumlah DPK dari tahun 2014 sampai 2018 yang terus meningkat, namun peningkatan jumlah DPK tidak diiringi dengan meningkatnya jumlah pembiayaan UMKM di bank syariah. Hal ini dapat ditunjukkan pada tabel I.1 dimana peningkatan jumlah DPK pada tahun 2015 meningkat sebesar Rp. 22,7 Triliun, akan tetapi jumlah pembiayaan UMKM menurun sebesar Rp. 26 Triliun. Hal ini semakin diperkuat oleh penelitian yang dilakukan oleh Ratu Vien S. Aziza dan Adie Sofyan Mulazid, jumlah DPK tidak berpengaruh terhadap pembiayaan Murabahah. (Aziza \& Mulazid, 2017)

Faktor lain yang dapat mempengaruhi pembiayaan adalah NPF yang merupakan rasio yang digunakan untuk melihat apakah pembiayaan suatu bank bermasalah atau tidak, sehingga kaitannya dengan pembiayaan yaitu semakin kecil nilai NPF bank artinya kualitas pembiayaan di bank tersebut semakin baik. maka pengaruhnya pada pembiayaan bank di tahun selanjutnya juga akan mengalami penurunan. Bank Indonesia telah menetapkan nilai NPF yang aman berada di bawah angka $5 \%$, artinya apabila bank memiliki nilai NPF lebih dari 5\% maka bank tersebut memiliki pembiayaan bermasalah. (Suhardjono, 2003) Data NPF di Bank Syariah pada tabel No. I.1 menunjukkan nilai NPF pada tahun 2016 meningkat dari 4,04\% menjadi 4,76\%, namun jumlah pembiayaan UMKM justru meningkat dari Rp.51,14 Triliun menjadi Rp. 51,25 Triliun. Hal ini dibuktikan oleh penelitian yang dilakukan oleh (Agustinar, 2014), yang menyatakan bahwa NPF berpengaruh secara negatif terhadap pembiayaan.

Pembiayaan bank syariah tidak hanya dipengaruhi oleh factor eksternal yaitu Inflasi. Menurut Jayanti dan Anwar ketika terjadi inflasi yang tinggi maka nilai riil uang akan turun sehingga mengakibatkan masyarakat lebih suka menggunakan uangnya untuk spekulasi. Hal ini akan merugikan perbankan syariah karena nasabah berpotensi melakukan penarikan uang dari perbankan (Jayanti \& Anwar, 2016). Dilihat dari tabel No.I.1 nilai Inflasi pada tahun 2014 sampai 2017 nilai inflasi memiliki pengaruh yang bertentangan dengan teori pada pengaruhnya terhadap pembiayaan UMKM. Pada tahun 2015 inflasi menurun sebesar 0,04\%, namun pembiayaan UMKM juga menurun sebesar Rp. 26 Triliun. Pada tahun 2017 inflasi mengalami kenaikan sebesar 0,28\%, namun jumlah pembiayaan UMKM meningkat sebesar Rp. 4,8 Triliun. Hal ini diperkuat oleh penelitian yang dilakukan oleh Agnes Dwi Astuti yang menyatakan bahwa tingkat inflasi berpengaruh tidak signifikan terhadap alokasi pembiayaan UMKM (Astuti, 2017) 
Berdasarkan uraian tersebut penulis tertarik untuk mengangkat tema "Pengaruh DPK, NPF, dan Inflasi terhadap Penyaluran Pembiayaan UMKM di Bank Syariah"

\subsection{Rumusan Masalah}

Berdasarkan latar belakang yang telah penulis uraikan di atas, maka permasalahan yang akan dikaji dan diteliti dalam penelitian ini adalah :

1. Apakah Dana Pihak Ketiga (DPK), Non Performing Financing (NPF) dan Inflasi berpengaruh secara parsial terhadap penyaluran pembiayaan UMKM di bank Syariah periode Januari 2014Desember 2018?

2. Apakah Dana Pihak Ketiga (DPK), Non Performing Financing (NPF), dan Inflasi berpengaruh secara simultan terhadap penyaluran pembiayaan UMKM di bank Syariah periode Januari 2014 - Desember 2018?

\section{Kajian Pustaka}

\subsection{Dana Pihak Ketiga}

Menurut Undang-Undang No.10 tahun 1998 tentang Perbankan pada pasal 1 ayat 5 memberikan pengertian simpanan pada bank adalah sebagai dana yang dipercayakan oleh masyarakat kepada bank berdasarkan perjanjian penyimpanan dana dalam bentuk giro, deposito, sertifikat deposito, tabungan dan atau bentuk lainnya yang dipersamakan dengan itu.

\subsection{Non Performing Financing}

Menurut Kamus Bank Indonesia, Non Performing Financing (NPF) adalah kredit bermasalah yang terdiri dari kredit yang berklasifikasi kurang lancar, diragukan dan macet. Tingkat NPF yang tinggi pada suatu bank syariah menunjukkan kualitas suatu bank yang tidak sehat. Bank Indonesia mengintruksikan perhitungan NPF dalam laporan keuangan perbankan nasional sesuai dengan Surat Edaran No.6/23/DPNP tanggal 31 Mei 2004, tentang perhitungan rasio keuangan bank yang dirumuskan sebagai berikut:

$$
\text { Non Performing Financing }(N P F)=\frac{\text { Pembiayaan Bermasalah }}{\text { Total Pembiayaan }} \times 100 \%
$$

\subsection{Inflasi}

Menurut Tripuspitorini \& Setiawan (2020) inflasi adalah proses dari suatu peristiwa, bukan tinggi rendahnya tingkat harga. Dengan demikian tingkat harga yang dianggap tinggi belum tentu menunjukkan inflasi. Inflasi dapat menjadi indikator untuk melihat tingkat perubahan serta dianggap terjadi jika proses kenaikan harga berlangsung secara terus-menerus dan saling pengaruh-mempengaruhi. Inflasi dibagi menjadi 3 tingkatan; inflasi ringan terjadi apabila kenaikan harga berada di bawah 10\%, inflasi sedang antara $10 \%$ sampai $30 \%$, dan inflasi berat antara 30\% sampai 100\%. Persentase tersebut di dapatkan dari rumus :

$$
\text { Tingkat Inflasi } t=\frac{\text { Tingkat Harga } \mathrm{t}-\text { Tingkat Harga } \mathrm{t}-1}{\text { Tingkat Harga } t-1} \times 100
$$

\subsection{Pembiayaan UMKM}

Menurut Peraturan Bank Indonesia Nomor 14/22/PBI/2012 Pembiayaan Usaha Mikro, Kecil, dan Menengah adalah Pembiayaan yang diberikan kepada pelaku usaha yang memenuhi kriteria Usaha Mikro, Kecil, dan Menengah. Terdapat dua jenis pembiayaan UMKM, yaitu pembiayaan UMKM untuk modal kerja dan pembiayaan UMKM untuk modal kerja. 
Pembiayaan modal kerja adalah pembiayaan yang diberikan bagi perusahaan untuk membiayai kebutuhan modal kerja usahanya berdasarkan prinsip syariah dan jangka waktu yang diberikannya maksimum satu tahun dan dapat diperpanjang sesuai kebutuhan.

\subsection{Inflasi}

1. Hubungan DPK terhadap Penyaluran Pembiayaan UMKM

Bank Syariah yang menjalankan fungsinya sebagai media intermediasi antara penghimpun dana dan penyalur dana mempunyai hubungan yang saling ketergantungan karena besarnya dana yang disalurkan oleh bank tergantung seberapa besarnya dana yang disediakan oleh bank melalui dananya seperti dana pihak ketiga (Anisa \& Tripuspitorini, 2019). Dana Pihak Ketiga sebagai salah satu sumber dana bank sangat penting dan berpengaruh terhadap keputusan bank dalam menyalurkan pembiayaan. Semakin besar jumlah Dana Pihak Ketiga, maka semakin besar penyaluran pembiayaan modal kerja. Berdasarkan penelitian Lita Istiani (2017) DPK berpengaruh positif terhadap alokasi pembiayaan UKM. (Istiani, 2017)

2. Hubungan NPF terhadap Penyaluran Pembiayaan UMKM

NPF merupakan risiko pembiayaan muncul jika bank tidak bisa memperoleh kembali cicilan pokok atau bunga dari pembiayaan yang diberikan atau investasi yang sedang dilakukan (Antonio, 2001). NPF juga biasa disebut sebagai risiko kredit, apabila nilai NPF tinggi, artinya pembiayaan di bank tersebut bermasalah, maka bank akan menurunkan jumlah pembiayaan untuk memperkecil risiko. Sehingga NPF memiliki pengaruh negatif terhadap pembiayaan UMKM. Menurut (Setyowati, 2019) dalam konsep perbankan syariah, jika jumlah pembiayaan menigkat maka kemungkinan risiko untuk pembaiyaan bermasalah semakin besar pula. Menurut Suhardjono semakin kecil NPF, maka kualitas pembiayaan akan semakin baik. (Suhardjono, 2003). Berdasarkan penelitian yang dilakukan oleh Ikromul Azhmi, bahwa NPF terbukti memiliki pengaruh negative terhadap pembiayaan di Bank Syariah (Azhmi, 2019).

3. Hubungan Inflasi terhadap Penyaluran Pembiayaan UMKM

Inflasi yang tinggi dapat menyebabkan penurunan daya beli masyarakat yang berakibat pada penurunan penjualan. Penurunan penjualan yang terjadi dapat menurunkan return perusahaan. Penurunan return yang terjadi akan mempengaruhi kemampuan perusahaan dalam membayar angsuran pembiaayan. Pembayaran angsuran yang semakin tidak tepat menimbulkan kualitas pembiayaan semakin buruk bahkan terjadi pembiayaan macet sehingga meningkatkan presentasi NPF semakin tinggi (Suyanto, 2017). Rasio NPF yang semakin tinggi akibat Inflasi akan menjadikan bank sangat berhati-hati dalam memberikan pembiayaan kepada kreditur dan bahkan mengurangi alokasi dananya pada pembiayaan, khususnya pembiayaan UMKM. Dengan demikian, inflasi memberikan pengaruh secara tidak langsung terhadap pembiayaan UMKM. Hal ini sejalan dengan penelitian Agnes Dwi, bahwa inflasi berpengaruh tidak signifikan terhadap pembiayaan UMKM. (Astuti, 2017) Berdasarkan pada penelitian sebelumnya, hipotesis yang diajukan dalam penelitian ini adalah:

Hipotesis $1 \quad$ : $\quad$ DPK berpengaruh positif terhadap Penyaluran Pembiayaan UMKM di Bank Syariah Periode 2014-2018

Hipotesis $2 \quad$ : NPF berpengaruh negatif terhadap Penyaluran Pembiayaan UMKM di Bank Syariah Periode 2014-2018

Hipotesis 3 : Inflasi berpengaruh negatif terhadap Penyaluran Pembiayaan UMKM di Bank Syariah Periode 2014-2018

Hipotesis $4 \quad$ : $\quad$ DPK, NPF, dan Inflasi berpengaruh signifikan secara simultan terhadap Penyaluran Pembiayaan UMKM di Bank Syariah Periode 2014-2018 


\section{Metode Penelitian}

Metode penelitian pada dasarnya merupakan cara ilmiah untuk mendapatkan data dengan tujuan dan kegunaan tertentu. Penelitian ini menggunakan metode kuantitatif, menurut Sugiyono (2005) metode kuantitatif yaitu metode penelitian yang berlandaskan pada filsafat, positivisme, digunakan untuk meneliti pada populasi atau sampel tertentu, pengumpulan data menggunakan instrumen penelitian, analisis data bersifat kuantitatif statistik, dengan tujuan untuk menguji hipotesis yang telah ditetapkan.

\subsection{Populasi dan Penentuan Sampel}

Populasi adalah wilayah generalisasi yang terdiri atas obyek/subyek yang mempunyai kualitas dan karakteristik tertentu yang ditetapkan oleh peneliti untuk dipelajari dan kemudian ditarik kesimpulannya. Populasi yang digunakan dalam penelitian ini adalah Bank Umum Syariah (BUS) dan Unit Usaha Syariah yang tersebar di seluruh Indonesia. Dari populasi tersebut, penulis menggunakan metode sampling jenuh, yaitu teknik penentuan sampel bila semua anggota populasi digunakan sebagai sampel (Sugiyono, 2017).

\subsection{Metode Pengumpulan Data}

Pengumpulan data merupakan langkah yang paling strategis dalam penelitian, karena tujuan utama dari penelitian adalah mendapatkan data. Tanpa mengetahui teknik pengumpulan data, maka peneliti tidak akan mendapatkan data yang memenuhi standar data yang ditetapkan (Sugiyono, 2005). Terdapat beberapa cara dalam menentukan metode pengumpulan data, dalam penelitian ini metode yang digunakan adalah Dokumentasi, yaitu dengan cara mengumpulkan, mencatat dan mengkaji data sekunder yang data perbankan Syariah yang bersumber dari Statistik Perbankan Syariah OJK dan Bank Indonesia.

\subsection{Variabel Penelitian dan Definisi Operasional Variabel}

Kerlinger menyatakan bahwa variabel adalah konstruk (constructs) atau sifat yang akan dipelajari. Dalam penelitian ini penulis menggunakan variabel dependen independen. Variabel bebas pada penelitian ini adalah penyaluran pembiayaan UMKM pada Bank Syariah. Menurut Sugiyono (2005) DPK menjelaskan mengenai sumber dana bank yang menjadi sumber penyaluran pembiayaan. NPF digunakan untuk merepresentasikan risiko kredit, dan Inflasi yang merupakan tingkat prosentase kenaikan harga dari indeks harga satu periode ke periode lain.

\subsection{Teknik Analisis Data}

Analisis data adalah kegiatan menghitung data agar dapat disajikan secara sistematis. Analisis data untuk penelitian kuantitatif bisa dilakukan secara manual dengan menghitung menggunakan rumus-rumus statistic seperti SPSS atau S-Plus (Priyatno, 2010). Teknik analisis yang digunakan dalam penelitian ini adalah uji asumsi klasik dan analisis regresi linier berganda, dengan didukung oleh data kuantitatif yang ada. Alat yang digunakan adalah SPSS.

Analisis regresi linier berganda digunakan untuk memprediksi parameter model regresi yaitu nilai konstanta $(\alpha)$ dan koefisien regresi $(\beta)$. Analisis ini digunakan dengan melibatkan dua atau lebih variabel bebas untuk meramalkan nilai variabel terikat $(Y)$. Analisis regresi linier berganda digunakan untuk mengetahui kuatnya hubungan antara beberapa variabel bebas secara serentak terhadap variabel terikat dan dinyatakan dengan rumus (Sugiyono, 2005).

\section{Hasil dan Pembahasan}

\subsection{Deskripsi Objek Penelitian}

Penelitian ini menggunakan objek dari Bank Umum Syariah yang berjumlah 14 BUS dan 20 UUS yang terdaftar di Otoritas Jasa Keuangan (OJK). Pada April 2020 jumlah seluruh BUS dan UUS tercatat ada sebanyak 2.331 unit di seluruh Indonesia, sedangkan data yang diambil 
adalah data dalam kurun waktu 5 (lima) tahun yaitu pada periode 2014-2018 untuk variable Dana Pihak Ketiga (DPK), Non Performing Financing, Inflasi, serta Pembiayaan UMKM.

\subsection{Analisis Data}

Statistik deskriptif merupakan bagian dari analisis data yang memberikan gambaran awal setiap variabel yang digunakan dalam penelitian. Penelitian ini menggunakan 4 (empat) variabel dalam menjelaskan deskriptif statistik, yang terdiri dari 1 (satu) variabel dependen dan 3 (tiga) variabel independen.

\subsection{Hasil Pengujian Asumsi Klasik}

\subsubsection{Uji Normalitas}

Ketentuan dalam pengambilan keputusan adalah jika nilai signifikansi (sig) pada kolom Kolmogorov-Smirnov lebih dari $(>) 0,05$ maka data berdistribusi normal dan jika kurang dari $(<) \quad 0,05$ maka data tidak berdistribusi normal. Hasil pengujian normalitas data penelitian ini sebagai berikut:

Tabel IV.1 Tabel Output Uji Normlitas KS-Z One-Sample Kolmogorov-Smirnov Test

\begin{tabular}{|ll|r|r|r|r|}
\hline & & $\mathrm{X} 1$ & $\mathrm{X} 2$ & $\mathrm{X} 3$ & $\mathrm{Y}$ \\
\hline $\mathrm{N}$ & & 55 & 55 & 55 & 55 \\
Normal Parameters $\mathrm{a}, \mathrm{b}$ & Mean & 4.8651 & 4.2471 & 4.4547 & .5565 \\
& Std. Deviation & .89032 & .71883 & 1.55396 & .05264 \\
& Absolute & .140 & .173 & .208 & .110 \\
Most Extreme Differences & Positive & .084 & .100 & .208 & .059 \\
& Negative & -.140 & -.173 & -.142 & -.110 \\
Kolmogorov-Smirnov Z & & 1.038 & 1.282 & 1.542 & .815 \\
Asymp. Sig. (2-tailed) & & .232 & .075 & .017 & .519 \\
\hline a. Test distribution is Normal. & & & & \\
b. Calculated from data. & &
\end{tabular}

Sumber: Hasil pengolahan data dengan SPSS

Pada tabel IV.1 terlihat bahwa Variabel X1，X2, X3 dan Y memiliki nilai signifikansi 0,232; 0,075; 0,017; dan 0,519. Seluruh nilai signifikansi menunjukkan angka lebih dari 0,05, maka data penelitian ini berdistribusi normal.

\subsubsection{Uji Multikolinearitas}

Untuk mendeteksi ada tidaknya masalah multikolinearitas dapat digunakan adalah dengan melihat nilai Tolerance dan VIF. Semakin kecil nilai Tolerance dan semakin besar VIF maka semakin mendekati terjadinya masalah multikolineraritas. Dalam kebanyakan penelitian menyebutkan bahwa jika Tolerance lebih dari 0,1 dan nilai VIF kurang dari 10, maka tidak terjadi multikolinearitas.

Tabel IV.2 Hasil Penghitungan Nilai Tolerance dan Nilai VIF

\begin{tabular}{|c|c|c|c|c|c|c|c|c|}
\hline \multicolumn{9}{|c|}{ Coefficients $^{\mathrm{a}}$} \\
\hline \multirow{2}{*}{\multicolumn{2}{|c|}{ Model }} & \multicolumn{2}{|c|}{$\begin{array}{l}\text { Unstandardized } \\
\text { Coefficients }\end{array}$} & \multirow{2}{*}{\begin{tabular}{c|}
$\begin{array}{c}\text { Standardized } \\
\text { Coefficients }\end{array}$ \\
Beta \\
\end{tabular}} & \multirow[t]{2}{*}{$\mathrm{t}$} & \multirow[t]{2}{*}{ Sig. } & \multicolumn{2}{|c|}{ Collinearity Statistics } \\
\hline & & $\mathrm{B}$ & Std. Error & & & & Tolerance & VIF \\
\hline \multirow{4}{*}{1} & (Constant) & .896 & .049 & & 18.282 & .000 & & \\
\hline & $\mathrm{X} 1$ & .009 & .008 & .160 & 1.184 & .242 & .382 & 2.615 \\
\hline & $\mathrm{X} 2$ & -.072 & .008 & -.986 & -8.550 & .000 & .525 & 1.904 \\
\hline & $\mathrm{X} 3$ & -.018 & .004 & -.522 & -4.583 & .000 & .537 & 1.861 \\
\hline
\end{tabular}

Sumber: Hasil pengolahan data dengan SPSS

Dari tabel IV.2 hasil penelelitian di atas terlihat bahwa nilai tolerance untuk X1, X2 dan X3 adalah sebesar 0,382; 0,525; dan 0,537. Angka-angka tersebut menunjukkan angka di atas 0,1. Nilai VIF untuk X1, X2, dan X3 adalah 2,617; 1,904; dan 1861, yang berada di bawah angka 10. Dari data tersebut dapat diambil kesimpulan bahwa data ini tidak terdapat masalah multikoliearitas. 


\subsubsection{Uji Heteroskedastisitas}

Untuk menguji masalah heteroskedastisitas pada penelitian ini digunakan metode Spearmean's rho dengan ketentuan jika nilai signifikansi antara variabel independent dengan residual lebih dari 0,05 maka tidak terjadi masalah heteroskedastisitas dan sebaliknya. Hasil penghitungan dengan menggunakan SPSS sebagai berikut:

Tabel IV.3 Hasil penghitungan heteroskedastisitas variable

\begin{tabular}{|c|c|c|c|c|c|c|}
\hline & & & $\mathrm{X} 1$ & $\mathrm{X} 2$ & $\mathrm{X} 3$ & $\begin{array}{c}\text { Unstandardized } \\
\text { Residual }\end{array}$ \\
\hline \multirow{12}{*}{$\begin{array}{l}\text { Spearman's } \\
\text { rho }\end{array}$} & \multirow{3}{*}{$\mathrm{X} 1$} & Correlation Coefficient & 1.000 & $.357^{* * *}$ & $-.675^{* *}$ & .094 \\
\hline & & Sig. (2-tailed) & & .007 & .000 & .495 \\
\hline & & $\mathrm{N}$ & 55 & 55 & 55 & 55 \\
\hline & \multirow{3}{*}{$\mathrm{X} 2$} & Correlation Coefficient & $.357^{* *}$ & 1.000 & -.258 & -.009 \\
\hline & & Sig. (2-tailed) & .007 & $\cdot$ & .058 & .948 \\
\hline & & $\mathrm{N}$ & 55 & 55 & 55 & 55 \\
\hline & \multirow{3}{*}{$\mathrm{X} 3$} & Correlation Coefficient & $-.675^{* *}$ & -.258 & 1.000 & .121 \\
\hline & & Sig. (2-tailed) & .000 & .058 & . & .380 \\
\hline & & $\mathrm{N}$ & 55 & 55 & 55 & 55 \\
\hline & \multirow{3}{*}{$\begin{array}{l}\text { Unstandardized } \\
\text { Residual }\end{array}$} & Correlation Coefficient & .094 & -.009 & .121 & 1.000 \\
\hline & & Sig. (2-tailed) & .495 & .948 & .380 & - \\
\hline & & $\mathrm{N}$ & 55 & 55 & 55 & 55 \\
\hline
\end{tabular}

Dari tabel IV.3 dapat diketahui bahwa nilai signifikansi untuk variable X1 adalah 0,495 atau $>0,05$ sedangkan untuk variable X2 adalah sebesar 0,948 atau $>0,05$ dan untuk variable X3 adalah sebesar 0,380. Karena semua nilai signifikansi lebih dari 0,05 maka dapat disimpulkan bahwa dalam model regesi tidak terjadi masalah heteroskedastistias.

\subsubsection{Uji Autokorelasi}

Untuk mengetahui adanya masalah autokorealsi maka digunakan uji Durbin Watson (DW test) dengan ketentuan jika dU $<$ DW $<4$-dU maka $\mathrm{H}_{0}$ diterima atau tidak terjadi autokorelasi. Hasil penghitungan dari data penelitian ini adalah sebagai berikut:

Tabel IV.4 Hasil Uji Autokorelasi Durbin Watson

\begin{tabular}{|l|r|r|r|r|r|}
\hline Model & R & R Square & Adjusted R Square & $\begin{array}{c}\text { Std. Error of the } \\
\text { Estimate }\end{array}$ & Durbin-Watson \\
\hline 1 & $.803^{2}$ & .644 & .623 & .03231 & 1.898 \\
\hline
\end{tabular}
a. Predictors: (Constant), X3, X2, X1
b. Dependent Variable: Y
Sumber: Hasil pengolahan data dengan SPSS

Dari tabel IV.4 hasil penghitungan tersebut terlihat bahwa nilai Durbin-Watson (DW) adalah sebesar 1.898. Sementara nilai $\mathrm{dL}$ dan $\mathrm{dU}$ pada tabel Durbin-Watson untuk $\mathrm{n}=55$ (jumlah data) dan $\mathrm{k}=3$ (variabel independen) adalah sebagai berikut $\mathrm{dL}=1.284$ dan $\mathrm{dU}=1.505$. Sehingga didapat penghitungan Durbin-Watson sebagai berikut: $4-\mathrm{dU}=4-1.505=2.496$ dan 4 $\mathrm{dL}=4-1.284=2.716$. Dari hasil penghitungan tersebut dapat dilihat bahwa posisi DW seperti pada gambar berikut: 


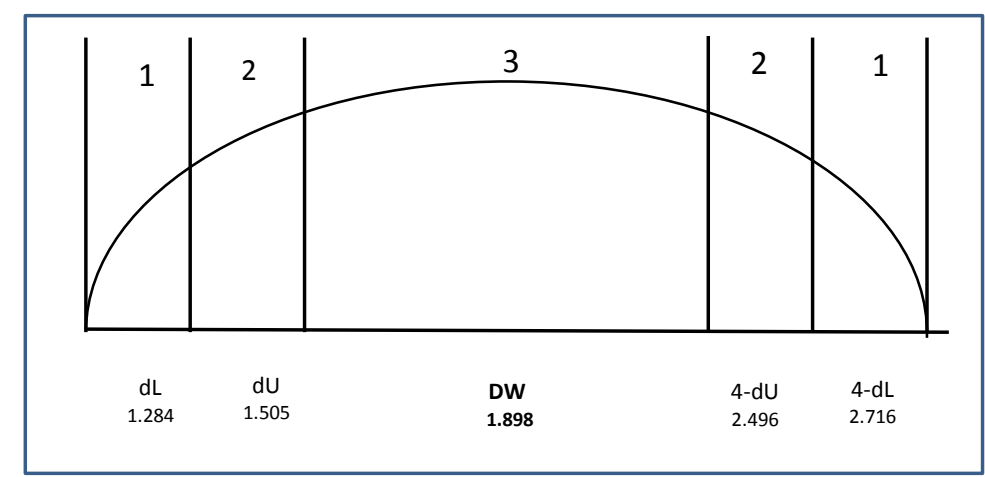

Gambar IV.1 Diagram Penentuan Posisi DW

Sumber : Hasil pengolahan data dengan SPSS

Keterangan:

1 = Daerah H0 ditolak (ada atuokorelasi)

$2=$ Daerah keragu-raguan (tidak ada keputusan yang pasti)

3 = Daerah H0 diterima (tidak ada autokorelasi)

Dari gambar IV.1 terlihat bahwa posisi DW berada pada area nomor 3 atau pada posisi $\mathrm{dU}<\mathrm{DW}<4$-dU atau $1.505<1.898<2.496$ maka $\mathrm{H}_{0}$ diterima atau tidak terjadi masalah autokorelasi pada penelitian ini.

\subsection{Analisis Regresi Linier}

\subsubsection{Uji F}

Uji F digunakan untuk menguji pengaruh variabel independen secara bersama-sama terhadap variabel dependen. Prosedur pengujiannya sebagai berikut:

Tabel IV.5 Hasil Penghitungan Nilai F

ANOVA $^{\mathrm{a}}$

\begin{tabular}{|ll|r|r|r|r|r|}
\hline Model & & Sum of Squares & \multicolumn{1}{c|}{ df } & Mean Square & F & Sig. \\
\hline \multirow{4}{*}{1} & Regression & .096 & 3 & .032 & 30.771 & $.000^{\text {b }}$ \\
& Residual & .053 & 51 & .001 & & \\
& Total & .150 & 54 & & & \\
\hline
\end{tabular}

a. Dependent Variable: $Y$

b. Predictors: (Constant), X3, X2, X1

Sumber: Hasil penghitungan SPSS, 2020.

Taraf signifikansi yang digunakan adalah 0,05. Dari tabel IV.5 terlihat bahwa hasil penghitungan $F_{\text {hitung }}$ adalah sebesar 30,771. $F_{\text {tabel }}$ dicari pada tabel statistic pada taraf signifikansi 0,05 df1 $=\mathrm{k}-1$ atau 3-1 = 2, dan df2 $=\mathrm{n}-\mathrm{k}$ atau $55-3=52(\mathrm{n}=$ jumlah data; $\mathrm{k}=$ jumlah variabel independen), dan besar $\mathrm{F}_{\text {tabel }}$ tersebut adalah sebesar 3,18. Jika $\mathrm{F}_{\text {hitung }}<\mathrm{F}_{\text {tabel }}$ maka $\mathrm{H}_{0}$ diterima. Diketahui bahwa $F_{\text {hitung }}>F_{\text {tabel }}$ atau 30,771 $>3,180$ maka $\mathrm{H} 0$ ditolak sehingga dapat disimpulkanbahwa Variabel DPK, Variabel NPF dan Variabel Inflasi secara bersama-sama berpengaruh signifikan terhadap Penyaluran Pembiayaan UMKM. Besar pengaruh ketiga variabel tersebut adalah sebesar 0,623 atau $62,3 \%$.

\section{IV.4.2 Uji t}

Uji t digunakan untuk menguji pengaruh variabel independen secara parsial terhadap variabel dependen. Prosedur pengujiannya sebagai berikut: 
Tabel IV.6 Hasil Penghitungan Nilai t

Coefficients $^{\mathbf{a}}$

\begin{tabular}{|c|c|c|c|c|c|c|}
\hline \multirow[t]{2}{*}{ Mod } & & \multicolumn{2}{|c|}{$\begin{array}{l}\text { Unstandardized } \\
\text { Coefficients }\end{array}$} & \multirow{2}{*}{$\begin{array}{c}\begin{array}{c}\text { Standardized } \\
\text { Coefficients }\end{array} \\
\text { Beta }\end{array}$} & \multirow[t]{2}{*}{$\mathrm{T}$} & \multirow[t]{2}{*}{ Sig. } \\
\hline & & $\mathrm{B}$ & Std. Error & & & \\
\hline \multirow{4}{*}{1} & (Constant) & .896 & .049 & & 18.282 & .000 \\
\hline & $\mathrm{X} 1$ & .009 & .008 & .160 & 1.184 & .242 \\
\hline & $\mathrm{X} 2$ & -.072 & .008 & -.986 & -8.550 & .000 \\
\hline & $\mathrm{X} 3$ & -.018 & .004 & -.522 & -4.583 & .000 \\
\hline
\end{tabular}

Sumber: Hasil penghitungan SPSS, 2020.

Taraf signifikansi yang digunakan adalah 0,05. Dari tabel IV.6 terlihat bahwa hasil penghitungan $\mathrm{t}_{\text {hitung }}$ untuk variabel $\mathrm{X} 1, \mathrm{X} 2$, dan $\mathrm{X} 3$ adalah sebesar 1,184; 8,550; dan 4,583. $\mathrm{t}_{\text {tabel }}$ dicari pada tabel statistik pada taraf signifikansi 0,05 dengan $\mathrm{df}=\mathrm{n}-\mathrm{k}-1$ atau $55-3-1=46$ ( $\mathrm{n}=$ jumlah data; $\mathrm{k}=$ jumlah variabel independen), dan besar $\mathrm{t}_{\text {tabel }}$ tersebut adalah sebesar 2,021. Pengambilan keputusan, Jika $t_{\text {hitung }}<t_{\text {tabel }}$ maka $\mathrm{H}_{0}$ diterima dan sebaliknya. Diketahui bahwa $t_{\text {hitung }} \mathrm{X} 1<\mathrm{t}_{\text {tabel }}$ atau $1,184<2,021$ maka $\mathrm{H}_{0}$ diterima sehingga dapat disimpulkan bahwa Variabel Dana Pihak Ketiga (DPK) secara parsial tidak berpengaruh signifikan terhadap Penyaluran Pembiayaan UMKM. Sedangkan untuk variabel X2 dan X3 memiliki nilai thitung $>$ $\mathrm{t}_{\text {tabel }}$ atau 8,550 dan 4,583 > 2,021 maka H0 ditolak sehingga dapat disimpulkan bahwa Variabel NPF dan Inflasi secara parsial berpengaruh signifikan terhadap Penyaluran Pembiayaan UMKM.

\section{IV.5 Analisis Koefisien Determinasi $\left(\mathbf{R}^{2}\right)$}

Berikut adalah hasil uji analisis RSquare;

Tabel IV.7 Hasil penghitungan R Square

Model Summary

\begin{tabular}{|l|r|r|r|c|}
\hline Model & $\mathrm{R}$ & $\mathrm{R}$ Square & Adjusted R Square & $\begin{array}{c}\text { Std. Error of the } \\
\text { Estimate }\end{array}$ \\
\hline 1 & $.803^{\mathrm{a}}$ & .644 & .623 & .03231 \\
\hline
\end{tabular}
a. Predictors: (Constant), X3, X2, X1
Sumber: Hasil penghitungan SPSS, 2020.

Berdasarkan tabel IV.7 nilai R Square menunjukkan angka 0,623 atau 62,3\%, artinya variabel X1, X2 dan X3 secara simultan berpengaruh terhadap variabel $Y$ sebesar $62,3 \%$, sedangkan sisanya $(37,7 \%)$ dipengaruhi oleh variabel lain di luar persamaan regresi ini atau variabel yang tidak diteliti seperti BI Rate, Return On Asset, PDB, FDR, dan lain-lain.

\subsection{Pembahasan}

\subsubsection{Pengaruh Dana Pihak Ketiga (DPK), Non Performing Financing (NPF), dan Inflasi Secara Parsial Terhadap Penyaluran Pembiayaan Usaha Mikro, Kecil Dan Menengah (UMKM) di Bank Syariah}

Hasil uji statistik pada tabel IV.11 menunjukkan bahwa DPK tidak berpengaruh signifikan terhadap penyaluran pembiayaan UMKM di Bank Syariah, karena perhitungan thitung adalah sebesar 1,184 dan $\mathrm{T}_{\text {tabel }}$ didapatkan sebesar 2,021, artinya $\mathrm{t}_{\text {hitung }}$ kurang dari $\mathrm{t}_{\text {tabel }}$. Artinya setiap kenaikan jumlah DPK tidak berpengaruh terhadap pembiayaan UMKM di Bank Syariah. Hasil penelitian ini berbeda dengan teori dan beberapa penelitian sebelumnya seperti Lita Istiani (2014), dan Agnes Dwi Astuti (2018) yang menyatakan bahwa DPK berpengaruh secara signifikan terhadap pembiayaan UMKM. Hal ini disebabkan jumlah DPK yang disalurkan pada pembiayaan UMKM dibandingkan dengan non UMKM jauh lebih sedikit dengan perbandingan $25 \%: 75 \%$, hal ini yang menjadikan perubahan jumlah DPK tidak berpengaruh pada penyaluran pembiayaan UMKM di Bank Syariah. Akan tetapi hasil penelitian ini sesuai dengan penelitian yang dilakukan oleh Debbi Chyntia dan Ayu Azillah, bahwa DPK berpengaruh negatif dan tidak signifikan 
terhadap pembiayaan musyarakah (Ovami \& Thohari, 2018).

Variabel kedua yaitu NPF, dari hasil penelitian membuktikan bahwa NPF berpengaruh signifikan terhadap penyaluran pembiayaan UMKM di bank syariah, karena hasil uji thitung sebesar 8,550 lebih besar dari dari $t_{\text {tabel }}$ sebesar 2,021. Hasil ini berbeda dengan beberapa penelitian sebelumnya seperti penelitian yang dilakukan oleh Agustina (2014), Debbi dan Ayu (2018), dan Ratu Vien dan Ade Sofyan (2017) yang menunjukkan hasil bahwa NPF berpengaruh negatif terhadap pembiayaan. Namun pada penelitian ini menunjukkan sebaliknya, karena data yang digunakan dalam penelitian ini menunjukkan bahwa nilai NPF cenderung meningkat, sedangkan jumlah pembiayaan UMKM terus menurun. Hasil ini sesuai dengan penelitian yang dilakukan oleh Mohammad Wahiduddin yang berjudul Pengaruh Inflasi, NPF, dan BI Rate Terhadap Pembiayaan UMKM pada Bank Umum Syariah 2012-2017. Pada penelitian tersebut menghasilkan keimpulan bahwa NPF mampu menjelaskan variabel pembiayaan UMKM (Wahiduddin, 2017)

Variabel selanjutnya yaitu inflasi. Berdasakan hasil penelitian, inflasi secara parsial berpengaruh signifikan terhadap penyaluran pembiayaan UMKM, karena hasil uji thitung sebesar $(4,583)$ lebih besar dari tabel yaitu sebesar 2,021. Hasil ini sesuai dengan penelitian yang dilakukan oleh Raden Ai Lutfi Hidayat (2016) yang berjudul Pengaruh Variabel Rasio Keuangan dan Makroekonomi Terhadap Pemberian Kredit Sektor UMKM oleh Perbankan di Indonesia, yang menyatakan bahwa inflasi berpengaruh signifikan positif terhadap kredit UMKM. Akan tetapi hasil ini tidak sesuai dengan teori dan beberapa penelitian sebelumnya sepertimpenelitian H. Muklis dan Thoatul Wahdaniyah (Wahdaniyah \& Muklis, 2016), Lita Istiani (Istiani, 2017) dan Ikromul Azhmi (Azhmi, 2019) yang menyatakan bahwa inflasi tidak berpengaruh terhadap pembiayaan UMKM di Bank Syariah. Inflasi berpengaruh terhadap pembiayaan UMKM karena data inflasi yang digunakan dalam penelitian ini cenderung turun dari tahun 2014 sampai 2018 dengan tingkat inflasi masih di bawah $10 \%$ yang artinya berada pada inflasi tingkat ringan.

\subsubsection{Pengaruh Dana Pihak Ketiga (DPK), Non Performing Financing (NPF), dan Inflasi Secara Simultan Terhadap Penyaluran Pembiayaan UMKM}

Berdasarkan hasil penelitian yang ditunjukkan pada table IV.10 Menyatakan bahwa Variabel DPK, NPF, dan Inflasi secara bersama-sama berpengaruh signifikan terhadap penyaluran pembayaan UMKM. Hasil ini dapat dibuktikan dari nilai $\mathrm{F}_{\text {hitung }}$ yang lebih besar dari $\mathrm{t}_{\text {hitung, }}$ yaitu sebesar 30,771 > 3,180, besar pengaruh ketiga variable tersebut sebesar 0,623 atau 62,3\%. Hasil ini sesuai dengan penelitian yang dilakukan H. Muklis dengan judul penelitian Pengaruh DPK, Inflasi, dan NPF Terhadap Pembiayaan UKM; Studi Pada Bank Syariah di Indonesia 20122013, hasil dari penelitian tersebut menyatakan bahwa ketiga variabel yaitu DPK, Inflasi, dan NPF berpengaruh signifikan terhadap pembiayaan pada UKM. (Muklis, 2014)

\section{Penutup}

Penelitian ini bertujuan untuk mengetahui pengaruhmDana Pihak Ketiga (DPK), Non Performing Financingm (NPF), dan Inflasi Terhadap Penyaluran Pembiayaan Usaha Mikro, Kecil dan Menengah (UMKM) pada Bank Syariah di Indonesia Periode 2014-2018. Hasil pengujian yang telah dilakukan dengan menggunakan alat analisis berupa SPSS, dapat disimpulkan sebagai berikut:

1. Dana Pihak Ketiga (DPK) tidak berpengaruh signifikan terhadap penyaluran pembiayaan UMKM di Bank Syariah, karena $t_{\text {hitung }}<t_{\text {tabel }}$ atau 1,184 $<2,021$. Non Performing Financing (NPF) berpengaruh signifikan terhadap penyaluran pembiayaan UMKM di Bank Syariah, karena thitung $>\mathrm{t}_{\text {tabel }}$ atau $8,550>2,021$. Inflasi berpengaruh signifikan terhadap penyaluran pembiayaan UMKM di Bank Syariah, karena thitung $>t_{\text {tabel }}$ atau 4,583 > 2,021. 
2. Variabel DPK, NPF, dan Inflasi secara bersama-sama berpengaruh signifikan terhadap penyaluran pembiayaan UMKM. Besarmpengaruh ketigamvariabel tersebut adalah sebesar 0,623 atau $62,3 \%$

Sebagai bahan masukan dan pertimbangan bagi pihak-pihak yang berkepentingan dengan penelitian ini maka penulis sampaikan hal-hal berikut:

1. Bagi bank syariah di Indonesia lebih meningkatkan pembiayaan khusunya sektor UMKM karena perkembangan UMKM yang terus meningkat dan dapat meningkatkan peluang untuk menumbuhkan perekonomian Indonesia.

2. Bagi pelaku UMKM, dapat mengajukan pembiayaan kepada Bank Syariah sebagai penambah modal. Karena sistem bagi hasil tidak terpengaruh pada tingkat inflasi dan NPF.

3. Bagi peneliti selanjutnya, dapat melakukan penambahan variabel baik yang berasal dari internal maupun eksternal, memperpanjang periode atau rentang waktu penelitian, sehingga mampu menggambarkan yang lebih realistis dan terkini mengenai faktor-faktor yang mempengaruhi penyaluran pembiayaan UMKM di Indonesia.

\section{Daftar Pustaka}

Agustinar. (2014). Analisis Pengaruh DPK, NPF, SWBI, dan SBPU Syariah Terhadap Penyaluran Pembiayaan Perbankan Syariah di Indonesia Periode 2010-2014. Program Pascasarjana UIN Medan, 127.

Anisa, L. S., \& Tripuspitorini, F. A. (2019). Analisis Pengaruh Dana Pihak Ketiga, Non Performing Finance Murabahah, Dan Inflasi Terhadap Pembiayaan Murabahan Pada Bank Umum Syariah Di Indonesia. Jurnal Maps (Manajemen Perbankan Syariab), 52-64.

Antonio, M. S. (2001). Bank Syariah Dari Teori Ke Praktik. Jakarta: Gema Insani Press.

Apriyanthi, R., Purbayati, R., \& Setiawan, S. (2020). Faktor-Faktor yang Mempengaruhi Pembiayaan Sektor Konstruksi pada Perbankan Syariah di Indonesia. ProBank, 5(1), 25-35.

Astuti, A. D. (2017). Pengaruh Jumlah Dana Pihak Ketiga (DPK), Inflasi, BI Rate, dan Financing To Deposit Ratio (FDR) Terhadap Alokasi Pembiayaan UMKM Pada Bank Umum Syariah Periode Juni 2014-Maret 2017. Fakultas Ekonomi dan Bisnis UIN Syarif Hidayatullah, 113.

Azhmi, I. (2019). Pengaruh Inflasi, Dana Pihak Ketiga (DPK), Non Perfoming Financing (NPF), Return Of Asset (ROA) Dan Sertifikat Bank Indonesia Syariah (SBIS) Terhadap Pembiayaan Usaha Kecil Dan Menengah Pada Perbankan Syariah Di Indonesia. Jurnal UIN Syarif Hidayatullah, 142-143.

Aziza, R. V., \& Mulazid, A. S. (2017). Analisis Pengaruh DPK, NPF, CAR, Modal Sendiri, dan Margin Keuntungan terhadap Pembiayaan Murabahah. JEBI (Jurnal Ekonomi dan Bisnis Islam)Volume 2, Nomor 1, Januari-Juni 2017, 13.

Istiani, L. (2017). Pengaruh Jumlah Dana Pihak Ketiga, Inflasi Terhadap Alokasi Pembiayaan Usaha Kecil dan Menengah (Studi Pada Perbankan Syariah di Indonesia Tahun 2008-2013). Jurnal Fakultas Ekonomi dan Bisnis Islam UIN Raden Intan Lampung, 124.

Jayanti, S. D., \& Anwar, D. (2016). Pengaruh Inflasi dan BI Rate Terhadap Pembiayaan Usaha Mikro, Kecil dan Menengah (Studi Kasus Pada Bank Umum Syariah). I-Economic Vol.2 No.2 December 2016, 86.

Muklis, H. (2014). Pengaruh DPK, Inflasi, Dan NPF Terhadap Pembiayaan UKM; Studi Pada Bank Syariah Di Indonesia 2012-2013. Jurnal Islaminomic Vol. V. No. 2, Agustus 2016, 25.

Ovami, D. C., \& Thohari, A. A. (2018). Pengaruh Dana Pihak Ketiga dan Non Performing Financing Terhadap Pembiayaan Musyarakah. Jurnal Penelitian Pendidikan Sosial Humaniora 
Vol. 3 No. $12018,302$.

PBI. (2012). Pemberian Kredit atau Pembiayaan oleh Bank Umum dan Bantuan Teknis Dalam Rangka Pengembangan Usaha Mikro, Kecil dan Menengah. Jakarta: Otoritas Jasa Keuangan.

Priyatno, D. (2010). Teknik Mudah dan Cepat Melakukan Analisis Data Penelitian Dengan SPSS dan Tanya Jawab Ujian Pendadaran. Yogyakarta: Gava Media.

Setyowati, D. H. (2019). Pengaruh Efisiensi Operasional Terhadap Return On Assets Pada Bank Umum Syariah di Indonesia. Jurnal Masharif al-Syariah: Jurnal Ekonomi dan Perbankan Syariah, $4(2), 39-53$.

Sugiyono. (2005). Metode Penelitian Administrasi. Bandung: Alfabeta.

Sugiyono. (2017). Metode Penelitian Kuantitatif, Kualitatif dan R\&D. Bandung: Penerbit Alfabeta.

Suhardjono. (2003). Manajemen Perkeditan Usaba Kecil dan Menengah. Yogyakarta: UPP AMR YKPN.

Tripuspitorini, F. A., \& Setiawan. (2020). Pengaruh Faktor Makroekonomi Terhadap

Pertumbuhan Dana Pihak Ketiga Pada Bank Umum Syariah di Indonesia. Jurnal riset Akuntansi dan Kenangan, 8(1), 121-132.

Wahdaniyah, T., \& Muklis. (2016). Pengaruh Dpk, Inflasi, Dan Npf Terhadap Pembiayaan Ukm; Studi Pada Bank Syariah Di Indonesia 2012-2013. Jurnal ISLAMINOMIC Vol. V. No. 2, Agustus 2016, 26-27.

Wahiduddin, M. (2017). Pengaruh Inflasi, NPF, dan BI Rate Terhadap Pembiayaan Usaha Mikro, Kecil dan Menengah Pada Bank Umum Syariah 2012-2017. Jurnal Politeknik Piksi Ganesha Bandung, 87.

Wahyudi, I. (2013). Manajemen Risiko Bank Islam. Jakarta: Salemba Empat. 